The editors of more than twenty-five documentation, library and archive journals met at the International Federation of Library Association's Conference in Grenoble, France, to discuss ways to foster greater cooperation among the world's library journals. One specific objective of the meeting was to follow up the symposium of editors, sponsored by UNESCO, which had been held May 16-19, 1972. Among the topics discussed at the IFLA meeting were international cooperation among editors of library journals, technical improvement, uniformity of bibliographical references, formats of transliteration systems, the content of authors abstracts, and the feasibility of publishing news of IFLA activities in national periodicals.

There seemed to be general agreement among the attendees that most editors and authors could benefit from the establishment of a clearinghouse. The clearinghouse would function as a communication link between authors and editors, as authors often do not know

Because of its interest to many academic librarians, the editors are publishing the following letter addressed to Robert Wedgeworth, Executive Director of ALA:

Because of your previously expressed interest in the New York Times-Kalvar microfilm problem, I have been directed by the members of the Micropublishing Projects subcommittee to report to you on recent developments in that matter. At the June 25 meeting of the subcommittee one of the members brought us up to date and gave his view that the particular type of Kalvar microfilm which the New York Times distributed to libraries for a time does not belong in the permanent collections of libraries since it is a continuing danger to other materials in its proximity.

This report was followed by statements by Mr. Benjamin Handelman and Mr. Karl Horwitz of the New York Times and Mr. Harold Harsh, President of Kalvar Corporation. Handelman and Horwitz took the position that because the Times subsidiary, Microfilming Corporation of America (MCA), did not have personnel with sufficient technical knowledge of Kalvar film, it was only logical to leave it to Kalvar Corporation to correct the problems which resulted from the sale of the film to several hundred libraries. The Times' representa- where to submit their manuscripts for publication. ( $C R L$ receives annually as many as ten misdirected manuscripts.) Inquiries from authors and publishers could be channeled through the clearinghouse to the most appropriate publication. UNESCO officials indicated that they would move to implement the clearinghouse concept.

The current inadequacies of library abstracting and indexing tools was also discussed. It is estimated by FID that over 700 journals in library science and documentation are not published. However, many significant publications are still not included in any of the major abstracting tools. UNESCO would like to encourage countries now lacking either an indexing or abstracting service to determine a way to cover the literature of their country. For some geographical areas, regional arrangements might prove to be more practical than a series of national plans.

\section{Tell It to the Times}

tives stated that to the best of their knowledge Kalvar was keeping its commitment to satisfy each aggrieved customer.

Mr. Harsh read a lengthy paper in which he recounted relative merits and problems of Kalvar and silver halide films and told of the efforts his company had made to educate and assist the affected libraries relative to the difficulties they were having with rusted cabinets and crumbling microfilm boxes.

After these statements a dialogue ensued between guests and members of the subcommittee on the one hand and the Times and Kalvar officials on the other. The former were primarily concerned with these points:

- The categorical unwillingness of the Times and MCA to deal with the aggrieved libraries.

- The failure of the Times and MCA to advise libraries of the dangers of the Kalvar film when they became known.

- The interpretation which Kalvar placed on the oft repeated Times' statement that "Kalvar will satisfy the customer." (It appears that Kalvar is not willing to go so far as to provide silver halide copies as replacement for Kalvar copies even if the complaining librarian insists that only that remedy will truly satisfy him. This despite 
the fact that in the past the Times made a number of such replacements.)

It is the opinion of the Micropublishing subcommittee that the subject microfilm does not belong in the permanent collections of libraries and that because of the circumstances under which this film was distributed, the New York Times Company has an obligation to provide replacement copies of the subject film with silver halide film for all libraries that desire it.

The subcommittee therefore recommends that any librarian who wants his Kalvar copies of the Times replaced with silver halide copies should so inform the Library and Information Services Division of the New York Times. Because of the emphasis Times officials have placed on the concept of satisfying the customer, the subcommittee recommends that any library which believes that the ultimate correction of its Times-Kalvar problem requires replacement of the film, should so tell the Times. We further recommend that copies of any such letters seeking redress be sent to you and to $\mathrm{Mr}$. Sidney Gruson, senior vice-president of the New York Times, because you have both indicated your desire to be kept aware of the true feelings of librarians in this important matter.

Lawrence S. Robinson, Chairman

Micropublishing Project Subcommittee

Resources and Technical Services Division

$\square$

\section{ALA/SRRT TASK FORCE ON WOMEN OFFERS JOB SERVICE}

The American Library Association/Social Responsibilities Round Table/Task Force on Women maintains a roster of women who are interested in administrative, management, or specialist positions in libraries. The women indicate on a standardized form basic resume, information including type of library and responsibilities preferred, educational and employment background, geographic restrictions, etc. The resumes are screened and matched to job openings as requests for resumes come in from employers. The service is free of charge, but we do request that women send a stamped, selfaddressed envelope when they request a roster form, and that employers return resumes when they have finished with them. For further information, resume forms, or employer requests contact the current roster coordinator: Liz Dickinson, Technical Services Division, Hennepin County Library, 7001 York Ave. So., Edina, MN 55435.

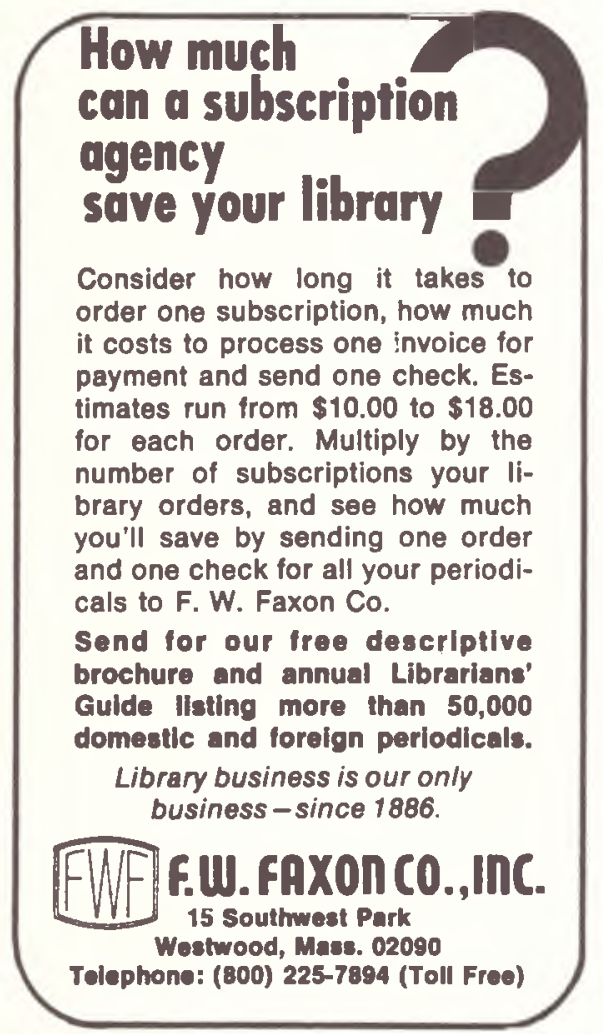

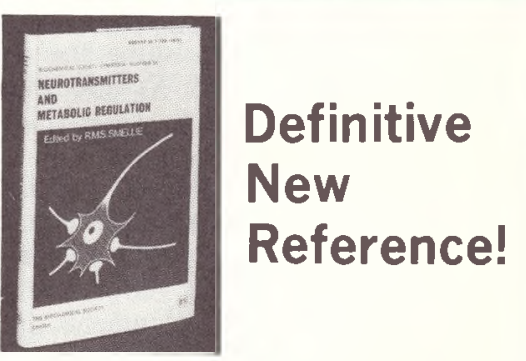

Biochemical Society Symposia: Number 36

\section{NEUROTRANSMITTERS AND METABOLIC REGULATION \\ Edited by R. M. S. Smellie}

A biochemical mapping that will bring researchers closer to an understanding of how the nervous system operates.

\section{$\$ 12.00$ per copy}

EBSCO SUBSCRIPTION SERVICES

Mr. R. Reese

P.O. Box 1943

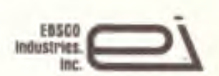

Birmingham, Alabama 35201

EBSCO Subscription Services is sole distributar in U.S.A., Canada and Mexico 